\title{
EFEK PERLAKUAN LOW TEMPERATURE LONG TIME BLANCHING TERHADAP KARAKTERISTIK CABAI KERING
}

\section{EFFECT OF LOW TEMPERATURE LONG TIME BLANCHING TREATMENT ON CHARACTERISTICS OF DRIED CHILIES}

\author{
Nunik Lestari $^{1 *)}$, Ratnawaty Fadilah ${ }^{1)}$, Andi Muhammad Akram Mukhlis ${ }^{1)}$, \\ Samsuar $^{2)}$ \\ ${ }^{1)}$ Program Studi Pendidikan Teknologi Pertanian, Fakultas Teknik, Universitas Negeri Makassar \\ ${ }^{2)}$ Program Studi Keteknikan Pertanian, Fakultas Pertanian, Universitas Hasanuddin \\ *Email: nunik.lestari@unm.ac.id
}

\begin{abstract}
ABSTRAK
Proses pretreatment sebelum cabai dikeringkan berperan penting untuk menghasilkan cabai kering dengan kualitas lebih baik. Penelitian ini bertujuan untuk melihat efek pretreatment LTLT blanching sebelum proses pengeringan terhadap karakteristik pengeringan dan kualitas cabai kering. Penelitian dilaksanakan dengan 12 perlakuan, yaitu pengeringan dengan pretreatment LTLT blanching pada suhu 60, 70, dan $80{ }^{\circ} \mathrm{C}$ masing-masing selama 10,15 , dan 20 menit, lalu pengeringan dengan pretreatment HTST blanching pada suhu $100{ }^{\circ} \mathrm{C}$ selama 10 detik, pengeringan tanpa pretreatment blanching di dalam alat pengering ERK, serta pengeringan tanpa pretreatment blanching di bawah sinar matahari secara langsung. Hasil penelitian menunjukkan pengaruh positif pretreatment LTLT blanching dapat mempercepat laju pengeringan, menghasilkan cabai kering dengan kadar air rendah sesuai standar SNI, menghasilkan warna cabai kering yang menarik, serta memiliki kandungan vitamin $\mathrm{C}$ lebih tinggi dibanding cabai kering tanpa pretreatment blanching. Secara keseluruhan, perlakuan pretreatment LTLT blanching pada suhu $80{ }^{\circ} \mathrm{C}$ selama 20 menit adalah perlakuan terbaik dari penelitian ini dengan kadar air akhir $8.17 \%$, laju pengeringan yang tercepat, kandungan vitamin $\mathrm{C}$ sebesar $0.96 \%$, dan warna yang menarik.
\end{abstract}

Kata kunci: cabai; pretreatment; pengeringan; vitamin $C$; warna

\section{ABSTRACT}

The pretreatment before drying chilies plays an important role to produce better quality of dried chilies. This study aims to determine the pretreatment effect of LTLT blanching before the drying process on the drying characteristics and quality of dried chilies. This research was carried out with 12 treatments, namely drying with LTLT blanching pretreatment at 60,70 , and $80^{\circ} \mathrm{C}$ for 10,15 , and 20 minutes respectively, then drying with HTST blanching pretreatment at $100^{\circ} \mathrm{C}$ for 10 seconds, drying without pretreatment blanching in the ERK dryer, and drying without pretreatment blanching in direct sunlight. The results show the positive effect of LTLT blanching pretreatment which can accelerate the drying rate, produce dry chilies with low water content according to SNI standards, produce an attractive dried chilies color, and have a higher vitamin $C$ than dried chilies without blanching pretreatment. Overall, pretreatment with LTLT blanching at $80^{\circ} \mathrm{C}$ for 20 minutes is the best treatment in this study with a final moisture content of $8.17 \%$, the fastest drying rate, a vitamin C content of $0.96 \%$, and an attractive color.

Keywords: chili; color; drying; pretreatment; vitamin C 


\section{PENDAHULUAN}

Cabai segar memiliki sifat perishable dan setelah dipanen mudah sekali mengalami kerusakan. Pengolahan cabai menjadi cabai kering merupakan salah satu solusi mengantisipasi kerusakan cabai lepas panen yang disebabkan proses respirasi. Cabai yang baru dipanen dapat langsung dikeringkan sehingga terhindar dari proses respirasi dan degradasi mutu. Cabai yang telah dikeringkan juga dapat disimpan dalam jangka waktu yang lebih lama dibanding cabai segar. Pengeringan cabai juga dapat menjadi salah satu solusi penanganan pascapanen cabai saat panen raya, dimana produksi cabai melimpah tetapi harga jualnya rendah. Dengan mengolah cabai menjadi cabai kering, maka harga jualnya akan lebih tinggi, umur simpannya relatif lebih panjang, jangkauan daerah pemasarannya lebih luas, dan terjamin ketersediaannya di setiap waktu.

Banyak jenis alat dan mesin pengeringan yang bisa digunakan untuk mengeringkan cabai, di antaraya adalah alat pengering tipe efek rumah kaca (ERK). Alat pengering ERK memiliki kelebihan mudah digunakan, mengeringkan cabai dalam kapasitas besar, dan menghasilkan cabai kering dengan kadar air rendah. Biaya operasional alat pengering ERK ini juga terbilang murah, karena energi panas yang digunakan berasal dari cahaya matahari yang terperangkap di dalam ruang pengering. Panas yang terperangkap ini akan meningkatkan suhu di dalam ruang pengering dan menurunkan kelembaban udaranya (Usman dkk., 2020). Penggunaan alat pengering ERK untuk pengeringan cabai juga lebih bersih dan terhindar dari debu dan kotoran dibanding dengan mengeringkan cabai di bawah sinar matahari secara langsung.

Proses pretreatment sebelum cabai dikeringkan berperan penting agar dapat menghasilkan cabai kering dengan kualitas yang baik (Khairunnisa, 2011). Salah satu cara pretreatment yang dapat dilakukanadalah blanching. Blanching adalah proses pemanasan dalam waktu cepat untuk menginaktivasi enzim. Blanching umumnya dilakukan dengan suhu mencapai $100{ }^{\circ} \mathrm{C}$, dengan air, uap air, ataupun energi microwave (Efendi dkk., 2015). Proses blanching sebelum pengeringan dapat mencegah reaksi browning pada cabai, baik reaksi browning secara enzimatik maupun non enzimatik. Reaksi browning ini sangat dihindari dalam proses pengeringan 
cabai karena merugikan.Salah satu kualitas cabai kering ditentukan oleh kecerahan warna.

Selain warna, kandungan vitamin C pada cabai kering juga perlu mendapatkan perhatian khusus. Cabai segar memiliki kandungan vitamin $\mathrm{C}$ yang tinggi dan bermanfaat sebagai antioksidan penting bagi tubuh (Orobiyi, et al., 2015). Tetapi, banyak kandungan vitamin $\mathrm{C}$ pada buah dan sayur yang menjadi rusak akibat penggunaan panas yang berlebihan dalam proses pengolahan (Igwemmar, et al., 2013). Proses blanching juga berpotensi merusak kandungan vitamin C pada cabai. Proses blanching, yang biasanya dilakukan dengan menggunakan media air pada suhu tinggi, dapat menyebabkan vitamin $\mathrm{C}$ pada cabai ikut terlarut ke dalam air.

Penelitian mengenai efek blanching sebagai pretreatment sebelum pengeringan cabai telah banyak dilakukan. Proses blanching yang dilakukan umumnya pada kisaran suhu tinggi dan waktu relatif singkat, yaitu 90-100 ${ }^{\circ} \mathrm{C}$ selama 0.6-9 menit seperti yang penelitian Murni dan Hartati (2010), Khairunnisa (2011), Tifani (2013), serta Bodra dan Ansari (2018). Belum banyak penelitian yang melaporkan tentang efek pretreatment blanching pada cabai dengan suhu rendah dan dalam waktu yang lama, atau yang biasa disebut dengan metode low temperature long time (LTLT) blanching. Padahal metode LTLT blanching terbukti efektif memperbaiki kualitas produk hasil pengeringan (Moehamed dan Hussein, 1994; Asgar dan Musaddad, 2008). Lebih spesifik lagi, masih jarang ditemui penelitian yang melaporkan tentang efek perlakuan LTLT blanching terhadap karakteristik pengeringan cabai menggunakan alat pengering ERK.

Dari uraian permasalahan tersebut, maka dilakukan penelitian yang bertujuan untuk mempelajari pengaruh pretreatment LTLT blanching sebelum proses pengeringan terhadap karakteristik pengeringan cabai, berupa kadar air, laju pengeringan, kualitas warna, dan kandungan vitamin $\mathrm{C}$.

\section{METODE PENELITIAN}

\section{Bahan dan Alat}

Bahan penelitian ini adalah cabai merah besar (Capsicum annuum L.). Alat utama pengeringan adalah pengering tenaga surya tipe efek rumah kaca (ERK), serta peralatan pendukung pengamatan dan analisis data yaitu termokopel, data logger, colorimeter, solar power meter, oven, desikator, 
hygrometer, timbangan, neraca analitik, buret, labu ukur, pipet, beaker glass, dan erlenmeyer.

\section{Prosedur Penelitian}

Ada 12 perlakuan pada penelitian ini, yaitu pengeringan dengan pretreatment LTLT blanching pada suhu 60,70 , dan $80{ }^{\circ} \mathrm{C}$ yang dilakukan masing-masing 10 menit, 15 menit, dan 20 menit, pengeringan dengan pretreatment HTST (hight temperature short time) blanching pada suhu $100{ }^{\circ} \mathrm{C}$ selama 10 detik, pengeringan cabai tanpa pretreatment blanching dalam pengering ERK, serta pengeringan cabai tanpa pretreatment blanching di bawah sinar matahari langsung. Proses blanching dilakukan menggunakan air tanpa penambahan natrium metabisulfit. Tujuannya untuk mengetahui pengaruh pretreatment LTLT blanching terhadap produk cabai kering yang dihasilkan tanpa pengaruh bahan tambahan lain.

Cabai yang digunakan pada penelitian ini telah melalui sortasi, pencucian, dan penirisan. Kriteria sortasi adalah cabai dengan bentuk utuh, tidak patah, dan berwarna merah merata pada keseluruhan buah. Untuk setiap perlakuan digunakan 500 gram cabai. Sampel cabai yang telah dicuci, ditiriskan, dan ditimbang selanjutnya diberi pretreatment sesuai perlakuan. Setelah itu cabai dihamparkan pada tray dan dikeringkan.

Proses pengeringan dilakukan selama 7 jam/hari, pada pukul 9.0016.00. Proses pengeringan berlangsung selama 5 hari. Lama waktu pengeringan ini adalah berdasarkan penelitian pendahuluan, dimana cabai yang dikeringkan selama 5 hari umumnya telah mencapai kadar air dibawah $11 \%$ untuk memenuhi standar SNI 01-33891994. Pengamatan yang dilakukan selama proses pengeringan berlangsung adalah penurunan massa cabai, suhu pengeringan, kelembaban udara, serta radiasi matahari. Pengukuran parameter pengamatan dilakukan setiap 1 jam.

\section{Analisis Data}

\section{Kadar Air}

Kadar air diukur dengan metode AOAC (2005) menggunakan Persamaan (1) dan (2) (Lestari dkk., 2020; Usman dkk., 2020; Irfan dkk., 2020):

$$
\begin{aligned}
M & =\frac{w(t)-d}{w(t)} \times 100 \% \\
X & =\frac{w(t)-d}{d}
\end{aligned}
$$

Di mana:

$\mathrm{M}=$ kadar air basis basah (\%), $\mathrm{X}=$ kadar air basis kering ( $\left.\mathrm{g}_{\text {air }} / \mathrm{g}_{\text {bahan kering }}\right), \mathrm{D}$ $=$ massa kering bahan $(\mathrm{g})$, dan $\mathrm{w}(\mathrm{t})=$ massa bahan saat $\mathrm{t}(\mathrm{g})$. 


\section{Laju Pengeringan}

Laju pengeringan adalah penurunan kadar air basis kering selama proses pengeringan berlangsung per satuan waktu, yang dihitung mengunakan persamaan (3) (Akpinar dan Toraman, 2016; Denglin et al., 2015):

$$
D_{R}=\frac{X_{t 1}-X_{t 2}}{t_{2}-t_{1}}
$$

Dimana $\mathrm{DR}=$ laju pengeringan ( $g_{\text {air }} / g_{\text {bahan kering.jam }),} \mathrm{X}_{\mathrm{t} 1}=$ kadar air basis kering saat $\mathrm{t}_{1}$ ( $\left.\mathrm{g}_{\text {air }} / \mathrm{g}_{\text {bahan kering }}\right), \mathrm{X}_{\mathrm{t} 2}$ $=$ kadar air basis kering saat $\mathrm{t}_{2}\left(\mathrm{~g}_{\mathrm{air}} / \mathrm{g}_{\text {bahan }}\right.$ kering), serta $t_{1}$ dan $t_{2}=$ waktu pengeringan (jam).

\section{Warna}

Ada 2 tahap analisis warna, yaitu analisis warna sampel cabai yang telah melalui proses blanching dan sebelum masuk ke proses pengeringan, serta pada produk akhir cabai kering. Analisis warna diukur menggunakan alat colorimeter. Data hasil pengukuran berupa nilai $L^{*}, a^{*}$, dan $b^{*}$.

\section{Vitamin C}

Pengukuran kadar vitamin $\mathrm{C}$ dilakukan pada sampel cabai yang telah melalui proses blanching serta pada produk akhir cabai kering dengan menggunakan metode titrasi iod
(AOAC, 2005). Pengujian diawali dengan menimbang sampel cabai sebanyak 5 gram dan dihaluskan. Sampel cabai dilarutkan dalam $100 \mathrm{ml}$ aquades, dan dilakukan penyaringan untuk memisahkan ampas. Selanjutnya filtrat dipipet sebanyak $20 \mathrm{ml}$ ke dalam erlenmeyer dan ditambahkan $1 \mathrm{ml}$ indikator pati $0.5 \%$. Titrasi dilakukan dengan larutan iodium $0.01 \mathrm{~N}$ hingga terbentuk warna biru kehitaman. Penentuan kadar vitamin $\mathrm{C}$ dihitung dengan Persamaan (4) (Tatengkeng dkk., 2019):

$$
\mathrm{V}_{\mathrm{C}}=\left(\frac{\mathrm{V}_{\mathrm{I}} \times 0.88 \times \mathrm{FP}}{\mathrm{W}}\right) \times 100 \%
$$

Dimana $\mathrm{V}_{\mathrm{C}}=$ kadar vitamin $\mathrm{C}(\%), \mathrm{V}_{\mathrm{I}}=$ volume iodin terpakai selama proses titrasi $(\mathrm{ml}), \mathrm{w}=$ massa sampel $(\mathrm{mg})$, dan $\mathrm{FP}=$ faktor pengenceran dalam pengujian kadar Vitamin C (5).

\section{HASIL DAN PEMBAHASAN}

\section{Suhu Pengeringan}

Suhu pengeringan sangat mempengaruhi kecepatan penurunan massa bahan yang dikeringkan. Semakin tinggi suhu pengeringan, maka bahan akan semakin cepat mengering. Tetapi untuk pengeringan cabai terdapat batasan suhuSuhu pengeringan yang sangat tinggi menyebabkan warna cabai kecoklatan dan kurang menarik. 
Hubungan antara suhu pengeringan, pengeringan berlangsung ditampilkan $\mathrm{RH}$, dan radiasi matahari selama proses pada Gambar 1.

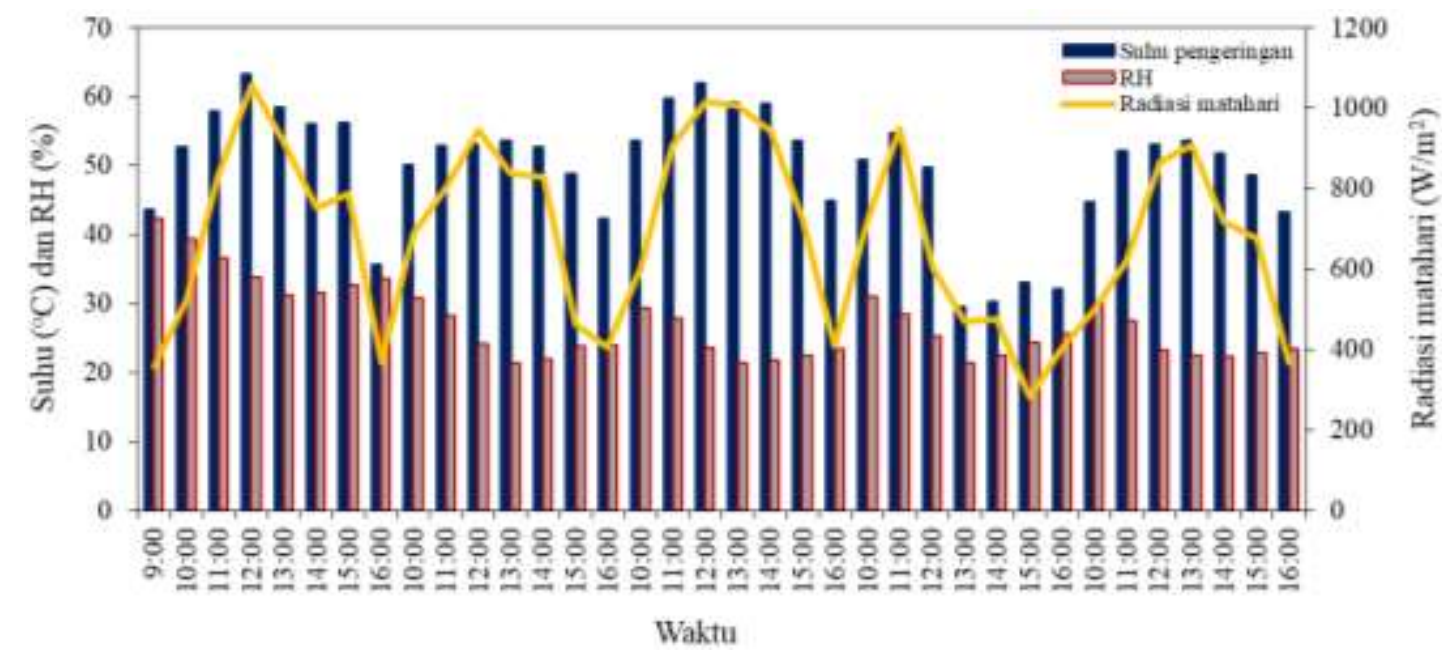

Gambar 1. Hubungan suhu pengeringan, RH, dan radiasi matahari selama pengeringan

Pada penelitian ini suhu pengeringan sangat dipengaruhi oleh intensitas penyinaran matahari. Jika cuaca baik dan intensitas penyinaran matahari tinggi tanpa tutupan awan, maka pengering ERK dapat mencapai suhu di atas $60{ }^{\circ} \mathrm{C}$. Suhu tertinggi biasanya terjadi pada puncak radiasi matahari (sekitar pukul 12.00-13.00). Suhu tertinggi saat pengeringan sebesar $63.3{ }^{\circ} \mathrm{C}$, sedangkan suhu rata-rata sebesar $50.21{ }^{\circ} \mathrm{C}$. Suhu rata-rata pengeringan ini sangat sesuai dan baik untuk pengeringan cabai, serta sejalan dengan penelitian Anoraga et al. (2018) bahwa suhu terbaik untuk pengeringan cabai berkisar $50-60{ }^{\circ} \mathrm{C}$. Pada kisaran suhu tersebut kandungan capsaicin cabai masih dapat dipertahankan dan diminimalisir kehilangannya, tetapi kadar air cabai kering dapat mencapai optimal (Jamilah dkk., 2019).

Gambar 1 juga menunjukkan hubungan terbalik antara suhu pengeringan dan kelembaban relatif $(\mathrm{RH})$. Semakin tinggi suhu maka $\mathrm{RH}$ akan semakin rendah. $\mathrm{RH}$ berpengaruh terhadap proses pemindahan uap air. Jika RH tinggi, maka perbedaan tekanan uap di dalam dan di luar bahan menjadi kecil, sehingga menghambat pemindahan uap air dari dalam menuju luar bahan. Kemampuan bahan untuk melepaskan air dari permukaan akan semakin besar dengan meningkatnya suhu udara di ruang pengering (Kemp, 2007; Omolola et al., 2015). 


\section{Kadar Air}

Kadar air cabai kering maksimal sesuai standar SNI 01-3389-1994 adalaah $11 \%$. Pada penelitian ini, umumnya sampel cabai dengan pretreatment blanching memiliki kadar air akhir sesuai standar SNI. Kadar air awal cabai untuk seluruh perlakuan \pm $83.16 \%$ (basis basah). Kadar air terendah setelah 5 hari pengeringan dicapai oleh perlakuan $80-20$ yaitu $8.17 \%$, sedangkan kadar air tertinggi dimiliki oleh perlakuan TB-ML yaitu $22.11 \%$. Grafik penurunan kadar air selama proses pengeringan cabai terdapat pada Gambar 2 dan Tabel 1.

Hasil penelitian menunjukkan bahwa pada perlakuan yang melibatkan pretreatment LTLT blanching, semakin lama waktu blanching maka semakin rendah kadar air akhir yang dicapai, yang berarti LTLT blanching selama 20 menit merupakan waktu yang terbaik. Namun jika dibandingkan antara tingkatan suhunya, yaitu 60,70 , dan 80 ${ }^{\circ} \mathrm{C}$, maka semakin tinggi suhu proses LTLT blanching maka akan semakin rendah kadar airnya. Diduga pada suhu blanching yang lebih tinggi terdapat lebih banyak kerusakan sel sehingga berpengaruh terhadap permeabilitas sel. Akibatnya, cabai menjadi lebih berpori dan jaringan lebih lunak, sehingga air dari dalam bahan menjadi lebih cepat keluar dan menguap, serta kadar air akhir pengeringan yang lebih rendah. Hal ini didukung penelitian Apriana dkk. (2016) \& Amanto dkk. (2015) bahwa blanching dengan suhu lebih tinggi menyebabkan permeabilitas pada membran sel sehingga menyebabkan air menjadi lebih mudah keluar.

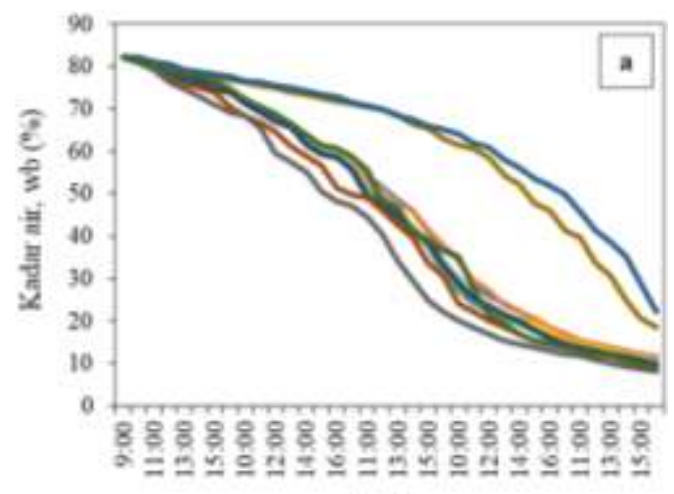

Waktu
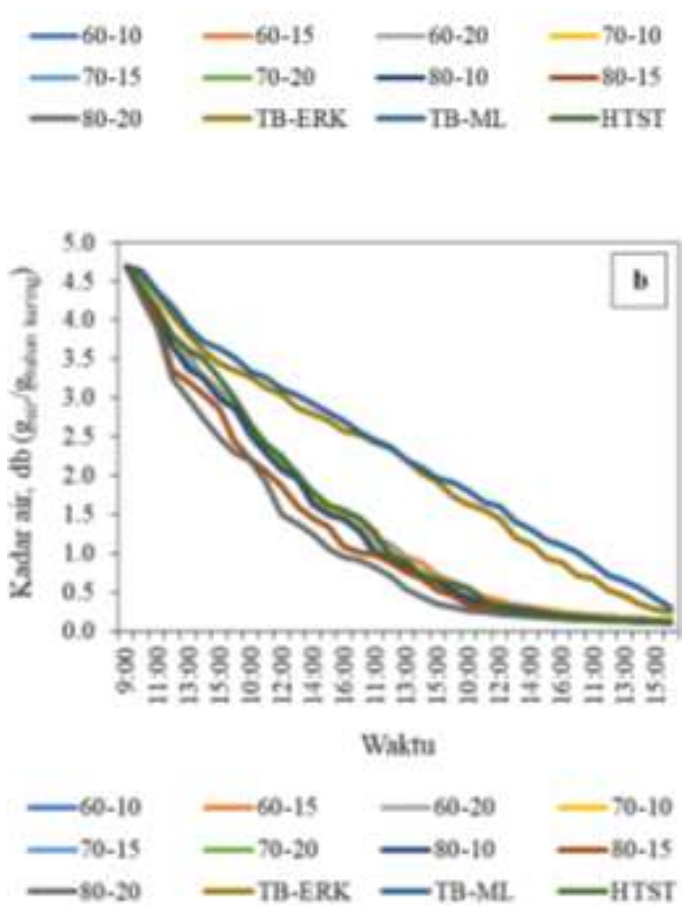

Gambar 2. Penurunan kadar air cabai selama proses pengeringan berlangsung (a) kadar air basis basah, dan (b) kadar air basis kering 
Jika dibandingkan dengan pretreatment HTST blanching, maka kadar air dari kedua pretreatment blanching tersebut tidak jauh berbeda. Namun perlakuan 80-20 tetap menghasilkan kadar air yang paling rendah. Jika dibandingkan dengan perlakuan kontrol tanpa proses blanching (TB-ERK dan TB-ML), maka kadar air cabai dengan pretreatment blanching jauh lebih rendah. Dalam waktu pengeringan yang sama, kadar air pada perlakuan TBERK dan TB-ML bahkan belum mencapai target yang ingin dicapai. Dan dari kedua perlakuan tersebut, kadar air pada perlakuan TB-ML adalah yang tertinggi. Hal ini disebabkan karena pada pengeringan perlakuan TB-ML suhu pengeringannya lebih rendah, dan pengeringannya hanya efektif berjalan saat matahari bersinar saja.

\section{Laju Pengeringan}

Laju pengeringan sampel dengan pretreatment blanching (LTLT dan HTST) lebih cepat dibandingkan dengan sampel tanpa pretreatment blanching (Gambar 3 dan Tabel 2). Hal ini menunjukkan bahwa pretreatment blanching secara umum dapat meningkatkan laju pengeringan. Hasil tersebut sejalan dengan Tunde-
Akintunde (2010) dan Akanbi et al. (2003). Peningkatan laju pengeringan disebabkan karena proses blanching membantu pelepasan air dari dalam ke permukaan bahan selama proses pengeringan berlangsung (Akanbi, et al., 2003). Hal ini karena adanya perubahan struktural pada bahan selama proses blanching yang menyebabkan terbukanya pori-pori bahan menjadi lebih besar (Hawa et al., 2020; Mazza, 1983). Selain itu menurut Karanthanos et al. (1997), proses blanching juga mengurangi efek ketebalan kulit yang merupakan ketahanan normal terhadap kehilangan air di permukaan bahan.

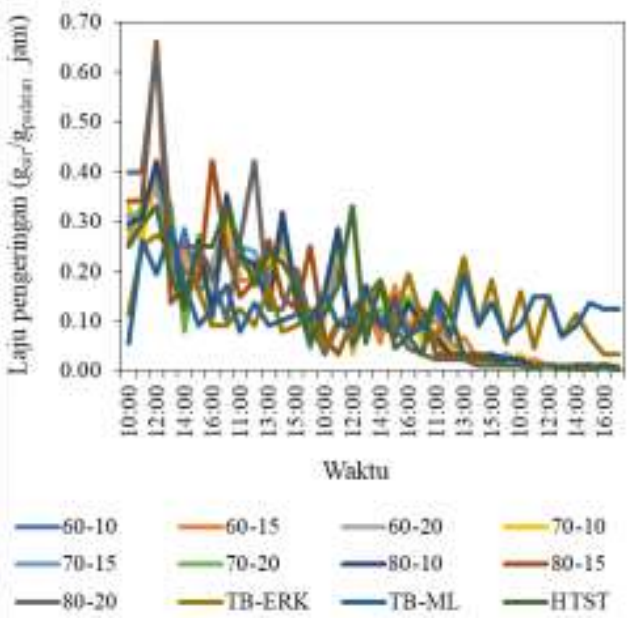

Gambar 3. Hubungan laju pengeringan cabai terhadap waktu

Gambar 3 juga memperlihatkan kurva laju pengeringan yang sangat fluktiatif, yang dipengaruhi fluktuasi suhu pengeringan akibat intensitas penyinaran matahari. Akan tetapi pada 
akhirnya laju pengeringan ini tetap menurun karena tidak ada lagi air bebas yang dapat diuapkan dan hanya menyisakan air terikat pada sel yang sulit berdifusi ke permukaan bahan. Hal ini sejalan dengan laju pengeringan pada produk pertanian lainnya seperti pada hasil penelitian Usman dkk. (2020) dan Lestari dkk. (2020).

\section{Warna}

Analisis warna yang ditampilkan pada Gambar 4 menunjukkan bahwa umumnya setelah melalui pretreatment blanching (LTLT dan HTST blanching), nilai $\mathrm{L}^{*}, \mathrm{a}^{*}$, dan $\mathrm{b}^{*}$ cabai mengalami peningkatan jika dibandingkan dengan cabai kontrol perlakuan TB-ML dan TB-ERK. Hal ini karena saat proses blanching terjadi peluruhan padatan terlarut pada cabai, sehingga penurunan jumlah padatan relatif tersebut menyebabkan peningkatan konsentrasi relatif karotenoid (Hossain et al., 2007). Kandungan karotenoid berperan terhadap warna merah pada cabai. Semakin tinggi kandungan karotenoid maka semakin merah warna cabai.

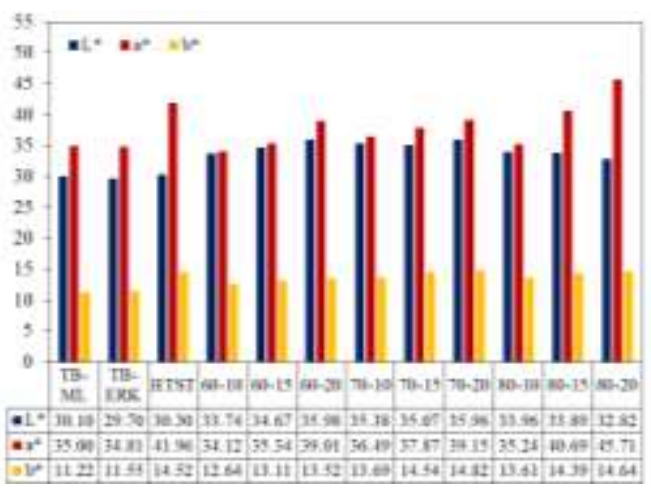

Gambar 4. Analisis warna cabai setelah blanching (sebelum masuk tahap pengeringan)

Sebaliknya, nilai $L^{*}, a^{*}$, dan $b^{*}$ warna pada produk cabai kering (Gambar 5) untuk semua perlakuan dengan pretreatment blanching lebih rendah dari perlakuan kontrol TB-ERK. Hal ini karena dalam durasi pengeringan yang sama (5 hari), cabai dengan pretreatment blanching seluruhnya telah mencapai kadar air dibawah $11 \%$ sebelum batas waktu pengeringan berakhir. Akibatnya, jika cabai yang telah kering tersebut terus dikeringkan/dipanaskan untuk memenuhi standar lama waktu pengeringan, maka diduga karotenoid pada cabai tersebut akan semakin mengalami kerusakan. Kerusakan ini disebabkan karena karotenoid pada cabai sangat sensitif terhadap suhu tinggi, sinar, serta udara (Dutta et al., 2004; Gregory, 1996; Irfan dkk., 2020). 
Tabel 1. Nilai hasil pengukuran dan perhitungan kadar air basis basah dan basis kering

\begin{tabular}{|c|c|c|c|c|c|c|c|c|c|c|c|c|c|}
\hline \multicolumn{14}{|c|}{ Kadar air basis basah $(\%)$} \\
\hline Hari ke & Waktu & $60-10$ & $60-15$ & $60-20$ & $70-10$ & $70-15$ & $70-20$ & $80-10$ & $80-15$ & $80-20$ & TB-ERK & TB-ML & HTST \\
\hline \multirow{2}{*}{1} & $9: 00$ & 83.160 & 83.160 & 83.160 & 83.160 & 83.160 & 83.160 & 83.160 & 83.160 & 83.160 & 83.160 & 83.160 & 83.160 \\
\hline & $16: 00$ & 74.189 & 73.962 & 73.885 & 73.962 & 73.808 & 74.038 & 73.885 & 70.599 & 69.277 & 76.757 & 77.578 & 74.704 \\
\hline \multirow{2}{*}{2} & $10: 00$ & 72.166 & 71.813 & 71.902 & 71.813 & 72.079 & 71.633 & 71.265 & 68.402 & 68.289 & 76.259 & 76.696 & 72.425 \\
\hline & $16: 00$ & 60.184 & 60.005 & 59.457 & 59.083 & 58.894 & 58.509 & 58.509 & 51.481 & 48.076 & 71.723 & 72.764 & 60.538 \\
\hline \multirow{2}{*}{3} & $10: 00$ & 58.118 & 57.719 & 57.313 & 56.688 & 56.261 & 55.826 & 55.605 & 49.836 & 47.149 & 71.358 & 71.542 & 58.702 \\
\hline & $16: 00$ & 37.909 & 37.909 & 34.230 & 31.700 & 31.171 & 32.221 & 33.241 & 30.633 & 22.114 & 63.004 & 65.180 & 36.579 \\
\hline \multirow{2}{*}{4} & $10: 00$ & 34.713 & 34.230 & 30.087 & 28.968 & 27.221 & 27.813 & 28.968 & 24.111 & 20.009 & 61.563 & 64.053 & 35.190 \\
\hline & $16: 00$ & 18.541 & 18.541 & 17.787 & 17.787 & 15.438 & 16.236 & 16.236 & 14.625 & 12.951 & 46.188 & 52.005 & 14.625 \\
\hline \multirow{2}{*}{5} & $10: 00$ & 17.019 & 17.019 & 15.438 & 15.438 & 14.625 & 14.625 & 14.625 & 13.796 & 12.089 & 41.199 & 49.836 & 13.796 \\
\hline & $16: 00$ & 11.713 & 11.581 & 10.530 & 10.367 & 10.195 & 9.821 & 9.748 & 8.868 & 8.170 & 18.541 & 22.114 & 9.166 \\
\hline \multicolumn{14}{|c|}{ Kadar air basis kering $\left(\mathrm{g}_{\text {air }} / \mathrm{g}_{\text {bahan kering }}\right)$} \\
\hline Hari ke & Waktu & $60-10$ & $60-15$ & $60-20$ & $70-10$ & $70-15$ & $70-20$ & $80-10$ & $80-15$ & $80-20$ & TB-ERK & TB-ML & HTST \\
\hline \multirow{2}{*}{1} & $9: 00$ & 4.695 & 4.695 & 4.695 & 4.695 & 4.695 & 4.695 & 4.695 & 4.695 & 4.695 & 4.695 & 4.695 & 4.695 \\
\hline & $16: 00$ & 2.918 & 2.884 & 2.873 & 2.884 & 2.861 & 2.896 & 2.873 & 2.440 & 2.292 & 3.351 & 3.511 & 2.998 \\
\hline \multirow{2}{*}{2} & $10: 00$ & 2.634 & 2.588 & 2.599 & 2.588 & 2.622 & 2.565 & 2.520 & 2.201 & 2.189 & 3.260 & 3.340 & 2.668 \\
\hline & $16: 00$ & 1.540 & 1.529 & 1.495 & 1.472 & 1.460 & 1.438 & 1.438 & 1.085 & 0.948 & 2.577 & 2.713 & 1.563 \\
\hline \multirow[b]{2}{*}{3} & $10: 00$ & 1.415 & 1.392 & 1.369 & 1.335 & 1.312 & 1.290 & 1.278 & 1.016 & 0.914 & 2.531 & 2.554 & 1.449 \\
\hline & $16: 00$ & 0.629 & 0.629 & 0.538 & 0.481 & 0.469 & 0.492 & 0.515 & 0.458 & 0.299 & 1.734 & 1.905 & 0.595 \\
\hline & $10: 00$ & 0.549 & 0.538 & 0.447 & 0.424 & 0.390 & 0.401 & 0.424 & 0.333 & 0.264 & 1.631 & 1.814 & 0.561 \\
\hline & 16:00 & 0.242 & 0.242 & 0.230 & 0.230 & 0.196 & 0.207 & 0.207 & 0.185 & 0.162 & 0.879 & 1.107 & 0.185 \\
\hline \multirow[b]{2}{*}{-} & $10: 00$ & 0.219 & 0.219 & 0.196 & 0.196 & 0.185 & 0.185 & 0.185 & 0.173 & 0.150 & 0.720 & 1.016 & 0.173 \\
\hline & $16: 00$ & 0.146 & 0.144 & 0.130 & 0.128 & 0.126 & 0.122 & 0.121 & 0.110 & 0.101 & 0.242 & 0.299 & 0.113 \\
\hline
\end{tabular}


Tabel 2. Nilai hasil perhitungan laju pengeringan

\begin{tabular}{cccccccccccccccc}
\hline \multicolumn{10}{c}{ Laju pengeringan $\left(\mathrm{g}_{\text {air }} / \mathrm{g}_{\text {bahan kering }}\right)$} \\
\hline \multirow{2}{*}{ Hari ke } & Waktu & $60-10$ & $60-15$ & $60-20$ & $70-10$ & $70-15$ & $70-20$ & $80-10$ & $80-15$ & $80-20$ & TB-ERK & TB-ML & HTST \\
\hline \multirow{2}{*}{1} & $10: 00$ & 0.285 & 0.262 & 0.319 & 0.330 & 0.308 & 0.285 & 0.296 & 0.342 & 0.399 & 0.114 & 0.057 & 0.251 \\
& $16: 00$ & 0.194 & 0.216 & 0.216 & 0.182 & 0.194 & 0.103 & 0.114 & 0.421 & 0.194 & 0.091 & 0.125 & 0.251 \\
\hline \multirow{2}{*}{2} & $10: 00$ & 0.285 & 0.296 & 0.273 & 0.296 & 0.239 & 0.330 & 0.353 & 0.239 & 0.103 & 0.091 & 0.171 & 0.330 \\
& $16: 00$ & 0.068 & 0.068 & 0.080 & 0.091 & 0.046 & 0.068 & 0.057 & 0.251 & 0.103 & 0.125 & 0.103 & 0.057 \\
\hline \multirow{2}{*}{3} & $10: 00$ & 0.125 & 0.137 & 0.125 & 0.137 & 0.148 & 0.148 & 0.159 & 0.068 & 0.034 & 0.046 & 0.159 & 0.114 \\
& $16: 00$ & 0.091 & 0.080 & 0.103 & 0.137 & 0.148 & 0.148 & 0.137 & 0.068 & 0.046 & 0.194 & 0.068 & 0.068 \\
\hline \multirow{2}{*}{4} & $10: 00$ & 0.080 & 0.091 & 0.091 & 0.057 & 0.080 & 0.091 & 0.091 & 0.125 & 0.034 & 0.103 & 0.091 & 0.034 \\
& $16: 00$ & 0.023 & 0.034 & 0.023 & 0.023 & 0.034 & 0.023 & 0.023 & 0.011 & 0.011 & 0.057 & 0.068 & 0.011 \\
\hline \multirow{2}{*}{5} & $10: 00$ & 0.023 & 0.023 & 0.034 & 0.034 & 0.011 & 0.023 & 0.023 & 0.011 & 0.011 & 0.159 & 0.091 & 0.011 \\
& $16: 00$ & 0.005 & 0.007 & 0.013 & 0.013 & 0.005 & 0.011 & 0.014 & 0.008 & 0.006 & 0.034 & 0.125 & 0.009 \\
\hline
\end{tabular}




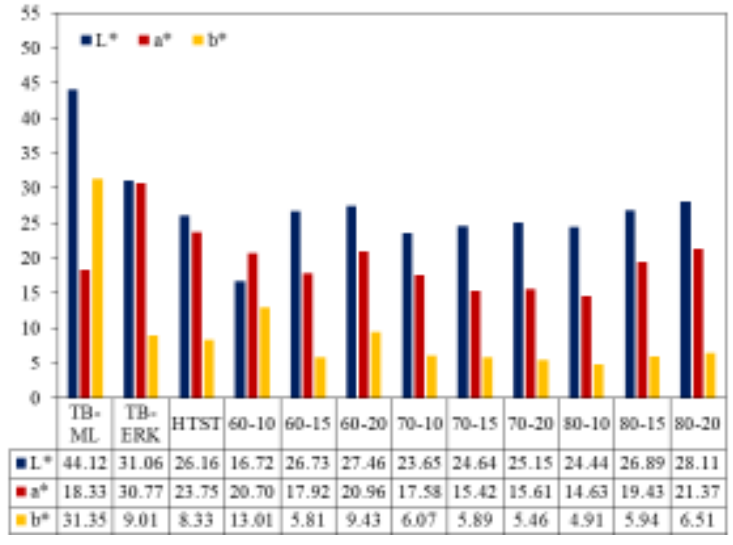

Gambar 5. Analisis warna cabai kering

Kerusakan karotenoid mudah terjadi pada cabai dengan pretreatment blanching karena cabai telah mengalami perubahan struktur dalam jaringan, kerusakan membran, kerusakan plasmalemma, serta beberapa degradasi pada dinding sel selama proses blanching (Nieto et al., 1998). Hal ini diduga menyebabkan komponen dalam cabai seperti karotenoid menjadi lebih mudah terdegradasi dibandingkan dengan cabai tanpa pretreatment blanching. Oleh sebab itu, pengeringan cabai dengan pretreatment blanching sebaiknya hanya dilakukan hingga cabai mencapai kadar air yang diinginkan, dan menghentikan proses pengeringan agar karoteniod pada cabai tidak terdegradasi.

Pada Gambar 4 dan 5 terlihat bahwa cabai pada perlakuan TB-ERK tidak menunjukkan penurunan nilai $\mathrm{L}^{*}$, $a^{*}$, dan $b^{*}$ yang terlalu jauh. Cabai kering pada perlakuan TB-ERK memiliki nilai $L^{*}$ dan $a^{*}$ tertinggi dari semua perlakuan dengan pretreatment blanching, yaitu $\mathrm{L}^{*}$ sebesar 31.05 dan a* sebesar 30.76, yang menunjukkan bahwa produk cabai keringnya berwarna merah cerah. Tetapi secara kasat mata, warna cabai kering dengan pretreatment blanching sebenarnya tidak berbeda dengan perlakuan TB-ERK. Cabai kering dengan pretreatment blanching memiliki warna yang merah pekat dengan kulit cabai yang mengkilap dan transparan. Warna merah cerah pada cabai kering perlakuan TB-ERK karena perlakuan tersebut tidak melalui blanching, sehingga karrotenoid tidak mengalami kerusakan karotenoid saat blanching. Selain itu, saat pengukuran cabai kering untuk perlakuan TB-ERK dalam kondisi kadar air yang tinggi yaitu $18.54 \%$, dan diduga karotenoid belum banyak mengalami kerusakan.

Kualitas warna untuk cabai kering dengan pretreatment blanching jauh lebih baik jika dibandingkan dengan cabai tanpa pretreatment blanching yang dikeringkan langsung di bawah sinar matahari (TB-ML). Pada perlakuan TBML warna cabai kering yang dihasilkan cenderung berwarna kuning pucat akibat tingginya kerusakan karotenoid selama 
proses pengeringan. Gambar 5 memperlihatkan dengan jelas bahwa perlakuan TB-ML memiliki nilai $\mathrm{L}^{*}$ dan $b^{*}$ yang sangat tinggi, yaitu $L^{*}$ sebesar 44.12 dan $b^{*}$ sebesar 31.35, yang menunjukkan cabai lebih berwarna kuning keputih-putihan. Hal ini karena perlakuan TB-ML cabai terpapar sinar matahari langsung dan udara terbuka, sehingga sebagian besar karotenoidnya terdegradasi. Sedangkan pada perlakuan lainnya cabai terlindungi karena berada dalam ruang pengering, sehingga penggunaan alat pengering ERK untuk cabai lebih baik dan direkomendasikan daripada pengeringan langsung di bawah sinar matahari.

\section{Vitamin C}

Pada Gambar 6 terlihat bahwa setelah proses blanching (HTST dan LTLT blanching) cabai mengalami penurunan kandungan vitamin $\mathrm{C}$ jika dibandingkan dengan cabai kontrol tanpa pretreatment blanching (TB-ML dan TBERK). Untuk pretreatment HTST blanching, penurunan vitamin $\mathrm{C}$ yang terjadi sejalan dengan pernyataan Burdurlu et al. (2006), bahwa semakin tinggi suhu pemanasan saat blanching maka kandungan vitamin $\mathrm{C}$ makin turun.
Dilain sisi, pada sampel cabai dengan pretreatment LTLT blanching semakin lama proses blanching dilakukan maka kandungan vitamin $\mathrm{C}$ akan semakin menurun. Proses blanching selama 20 menit adalah yang paling banyak menurunkan kandungan vitamin C. Hal ini sesuai dengan pernyataan Almatsier (2001) dan Vishwanathan et al. (2013) bahwa kerusakan vitamin $\mathrm{C}$ disebabkan oleh beberapa faktor seperti pemanasan dalam waktu lama, perendaman dalam air, serta pemanasan dalam alat dari besi atau tembaga. Ketiga faktor tersebut terdapat pada proses LTLT blanching.

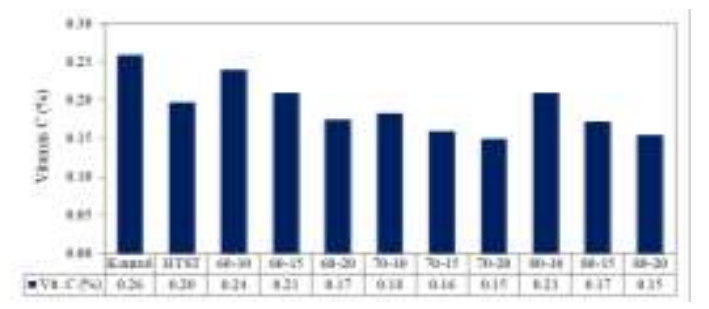

Gambar 6. Analisis kandungan vitamin C setelah blanching (sebelum masuk tahap pengeringan)

Gambar 7 menunjukkan bahwa semua cabai kering yang sebelumnya diproses dengan pretreatment blanching memiliki kandungan vitamin $\mathrm{C}$ yang lebih tinggi dari cabai kontrol TB-ERK dan TB-ML. Hal ini diduga karena cabai kering dengan pretreatment blanching memiliki kadar air yang jauh lebih rendah 
dibanding dengan cabai tanpa pretreatment blanching (Tabel 1), sehingga untuk massa sampel pengujian vitamin C yang sama (5 gram) maka cabai dengan pretreatment blanching akan memiliki lebih banyak bahan padatan kering. Hasil ini sejalan dengan hasil penelitian Anoraga et al. (2018) dan Vishwanathan et al. (2013) yang juga melakukan pretreatment blanching sebelum proses pengeringan.

Perlakuan LTLT blanching pada suhu $80{ }^{\circ} \mathrm{C}$ selama 20 menit adalah perlakuan dengan kandungan vitamin $\mathrm{C}$ tertinggi, yaitu $0.96 \%$. Vitamin C pada perlakuan 80-20 ini juga jauh lebih tinggi dari perlakuan HTST blanching yang hanya sebesar $0.87 \%$. Hal ini karena cabai kering pada perlakuan $80-20$ memiliki kadar air yang paling rendah jika dibanding perlakuan lainnya, sehingga memiliki lebih banyak bahan padatan kering dalam takaran sampel pengujian yang sama.

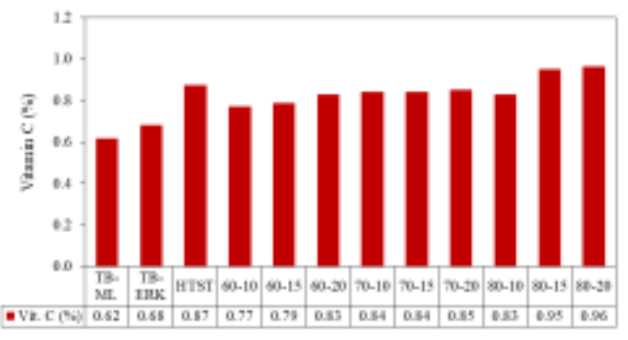

Gambar 7. Analisis kandungan vitamin cabai kering

\section{DAFTAR PUSTAKA}

AOAC. 2005. Official Method of Analysis of The Association of Official Analytical Chemist. AOAC. Washington DC.

Akanbi, C. T., Olumese, A. O., Taiwo, K. A., Ojo, A., and Akinwande, B. A. 2003. Effect of blanching medium on drying and storage characteristics of pepper. In Nigerian Drying Symposium Series. 1: 95-107.

Akpinar, E. K., and S. Toraman. 2016. Determination of Drying Kinetics and Convective Heat Transfer Coefficients of Ginger Slices. Heat and Mass Transfer. 52: 2271-2281.

Almatsier, S. 2001. Prinsip-Prinsip Ilmu Gizi. Gramedia Pustaka. Jakarta.

Amanto, B. S., S. Siswanti dan A. Atmaja. 2015. Kinetika Pengeringan Temu Giring 
(Curcuma heyneana valeton and van zijp) Menggunakan Cabinet Dryer dengan Perlakuan Pendahuluan Blanching. Jurnal Teknologi Hasil Pertanian. 8 (2): 107-114.

Anoraga, S. B., I. Sabarisman, and M. Ainuri. 2018. Effect of Different Pretreatments on Dried Chilli (Capsicum annum L.) Quality. in IOP Conference Series: Earth And Environmental Science. 131: 012014-012014. IOP Publishing.

Apriana, D., E. Basuki dan A. Alamsyah. 2016. Pengaruh Suhu dan Lama Blanching terhadap Beberapa Komponen Mutu Tepung Ubi Jalar Ungu (Ipomoea batatas L). Pro Food. 2(1): 94-100.

Asgar, A., dan D. Musaddad. 2008. Pengaruh Media, Suhu, dan Lama Blansing Sebelum Pengeringan Terhadap Mutu Lobak Kering. Jurnal Hortikultura. 18(1): 87-94.

Bodra, N., and I.A. Ansari. 2018. Optimization of Blanching Treatments of Green Chilli. International Journal of Chemical Studies. 6(6): 486-489.

Burdurlu, H. S., N. Koca, and F. Karadeniz. 2006. Degradation of Vitamin $\mathrm{C}$ in Citrus Juice Concentrates During Storage. Journal Of Food Engineering. 74(2): 211-216.

Denglin, L., L. Juan, L. Yunhong, and R. Guangyue. 2015 Drying Characteristics and Mathematical Model of Ultrasound Assisted HotAir Drying of Carrots. International Journal of Agricultural and
Biological Engineering. 8(4): 124132.

Dutta, D., U. Raychaudhuri, and R. Chakraborty. 2004. Retention of BCarotene in Frozen Carrots under Frying Condition of Temperature and Time of Storage. African Journal of Biotechnology. 4(1): 102-108.

Efendi, Z., F.E.D. Surawan dan Winarto. 2015. Efek Blanching dan Metode Pengeringan terhadap Sifat Fisikokimia Tepung Ubi Jalar Orange (Ipomoea batatas L.). Jurnal Agroindustri. 5(2): 109-117.

Gregory, J. F. 1996. Vitamins. In: Food Chemistry (edited by O.R. Fennema), 3rd edn. Marcel Dekker. New York.

Hawa, L. C., N.I.W. Yosika, A.N. Laily, F.N. Affifah dan D.M. Maharani. 2020. Perubahan Fisiko-Kimia Cabai Puyang (Piper retrofractum vahl.) pada Pengeringan Hot Air Dryer. Jurnal Teknologi Pertanian, 21(2): 128-135.

Hossain, M. A., J.L. Woods and B.K. Bala. 2007. Single-Layer Drying Characteristics and Colour Kinetics of Red Chilli. International Journal of Food Science and Technology. 42(11): 1367-1375.

Igwemmar, N. C., S.A. Kolawole, and I.A. Imran. 2013. Effect of Heating on Vitamin C Content of Some Selected Vegetables. International Journal of Scientific and Technology Research. 2(11): 209212. 
Irfan, A. M., A. Arimansyah, A.R. Rasyid \& N. Lestari. 2020. Unjuk Kerja Pengering Tenaga Surya Tipe Efek Rumah Kaca untuk Pengeringan Cabai dengan Perlakuan Low Temperature Long Time Blanching. Jurnal Rona Teknik Pertanian, 13(2): 42-58.

Jamilah, M., K. Kadirman dan R. Fadilah. 2019. Uji Kualitas Bubuk Cabai Rawit (Capsicum frutescens) Berdasarkan Berat Tumpukan dan Lama Pengeringan Menggunakan Cabinet Dryer. Jurnal Pendidikan Teknologi Pertanian. 5(1): 98-107.

Kemp, I. C. 2007. Humidity Effects in Solids Drying Processes. Measurement and Control. 40(9): 268-271.

Khairunnisa. 2011. Pengaruh Pretreatments pada Pengeringan Cabai Merah (Capsicum annuum L.) dengan Mesin Pengering Tipe Rak (Tray Dryer). [Skripsi]. Fakultas Teknologi Pertanian Institut Pertanian Bogor. Bogor.

Lestari, N., S. Samsuar, E. Novitasari \& K. Rahman. 2020. Kinerja Cabinet Dryer pada Pengeringan Jahe Merah dengan Memanfaatkan Panas Terbuang Kondensor Pendingin Udara. Jurnal Agritechno, 13(1): 57-70. https://doi.org/10.20956/at.v13i1.25 0

Mazza, G. 1983. Drying of Carrots: Effect of Pre-Drying Treatments on Moisture Transport and Product Quality. Journal of Food Technology. 18: 113-123.
Moehamed, S. and R. Hussein. 1994. Effect of Low Temperature Blanching, Cysteine-Hcl, N-AcetylLcysteine, Na-Metabisulphite, and Drying Temperature on the Firmness and Nutrient Content of Dried Carrots. Journal of Food Processing and Preservation. 18: 343-348.

Murni, M., dan M.E. Hartati. 2010. Pengaruh Perlakuan Awal dan Blansing Terhadap Umur Simpan Cabai Merah Kering. Berita Litbang Industri. XLV(3): 45-51.

Nieto, A., D. Salvatori, M.A. Castro and S.M. Alzamora. 1998. Air Drying Behaviour of Apples as Affected by Blanching and Glucose Impregnation. Journal of Food Engineering. 36(1): 63-79.

Omolola, A. O., A.I.O Jideani, and P.F. Kapila. 2015. Drying Kinetics of Banana (Musa spp.) Interciencia. 40(6).

Orobiyi, A., H. Ahissou, F. Gbaguidi, F. Sanoussi, A. Houngbèmè, A. Dansi, and A. Sanni. 2015. Capsaicin and Ascorbic Acid Content in the High Yielding Chili Pepper (Capsicum annuum L.) Landraces of Northern Benin. International Journal of Current Microbiology and Applied Sciences. 4(9): 394-403.

Tatengkeng, M. A., I.S. Setiasih dan D.M. Sumantri. 2019. Kadar Vitamin C Cabai Rawit (Capsicum frutescens L) Hasil Ozonasi Selama Penyimpanan Suhu Ruang. Pasundan Food Technology Journal (PFTJ). 6(2): 102-104. 
Tifani, K. T. 2013. Karakteristik Pengeringan Cabai Merah (Capsicum annuum L.) sebagai Pewarna Alami Kosmetik. [Skripsi]. Fakultas Teknologi Pertanian Institut Pertanian Bogor. Bogor.

Tunde-Akintunde, T. Y. 2010. Effect of Pretreatment on Drying Time and Quality of Chilli Pepper. Journal of Food Processing and Preservation. 34(4): 595-608.

Usman, U., A. Muchtar, U. Muhammad \& N. Lestari. 2020. Purwarupa dan Kinerja Pengering Gabah Hybrid Solar Heating dan Photovoltaic Heater dengan Sistem Monitoring Suhu. Jurnal Teknik Elektro, 12(1): 24-32.

https://doi.org/10.15294/jte.v12i1.2 4028 .

Vishwanathan, K. H., G.K. Giwari and H.U. Hebbar. 2013. Infrared Assisted Dry-Blanching and Hybrid Drying of Carrot. Food and Bioproducts Processing. 91: 89-94. 